\title{
Digital Learning Games Scale (DLGS): A Scale Development Study
}

\author{
https://doi.org/10.3991/ijet.v16i11.20709
}

\author{
Yasmeen Nzam Abu Mukh, Sherine Adnan Hashaikeh, \\ Aysha Mohamad Abd-Rabo ${ }^{(凶)}$ \\ An-Najah National University Nablus, Nablus, Palestine \\ ayshe.abdraboestu.najah.edu
}

\begin{abstract}
The purpose of this study is to develop a valid and reliable measurement tool for measuring contribution of digital learning games in the learning process. The study group consists of 280 teachers working in elementary schools in Palestine in the 2020-2021 academic year. The construct validity of the scale was examined by exploratory factor analysis. According to the results of the analysis, the scale measures a six- dimensions structure. The six dimensions structure of the scale was confirmed by stepwise linear regression analysis. The total variance ratio explained by the scale was determined as 68.38. In order to determine the reliability of the scale, the internal consistency coefficient of Cronbach's alpha was evaluated and this value was determined as 914. The results of all validity and reliability analyzes show that the digital leaning game as a valid and reliable measurement tool in the future studies about digital learning games.
\end{abstract}

Keywords-Digital games, scale, factor analysis

\section{Introduction}

Rapid technological and scientific developments changed our daily way of life clearly, due to the huge information explosion in science and technology, and this period was called the information society which was characterized by producing knowledge in all its forms and focusing on the relationship between science and technology [1]. The development in computer and internet technologies has motivated research in the different educational aspects, including learning [2-3], teaching [4-5] and teacher education [6-7]. In the present research, we study learning aspect as it is impacted by educational technology, specifically digital games.

The young generation of today is growing up in networked interactive media world where high-speed information acquisition, instant rewards, educational landscape reacts by introducing social media, ICT and mobile technologies to reach new learner audience and apply these media as an educational tool on a preschool, elementary, secondary, and higher levels. Students are often lazy when it comes to studying, and how to motivate them is one of the most important problems of education, the digital games and canning play a prominent role in motivating students and supporting their 
learning [8]. Most recently, instructional designers have been examining how best to use digital games in education. Digital games are a common term in education, they have been defined as an environment that provides an opportunity to learn by playing by providing a virtual environment governed by disciplines, rules, and restrictions that combine competition, motivation, and learning [9].

Games, in general, attract the interest of the majority of individuals of all ages, they have many positive effects on participation and motivation of individuals, meeting human needs and desires and facilitating them working to produce solutions to everyday problems [10]. Games often require competition and challenge, and lead to emotional reactions by learners and achieving many of the learning goals [11]. Digital games were suggested in the frame of innovate models of learning using the Internet and multimedia, and have contributed greatly to the learning process as they contribute to enhancing the 21st century skills of learners [12]. The Digital learning games play a major role in promoting the learning process, and help students from different ages to be self-learners and help them to solve many problems in their real life. They contribute to the development of many aspects related to the learning process; therefore, the current study tries to legalize a scale to measure the dimensions of Digital learning games in the learning process.

\subsection{The rationale, goals, and questions of the study}

The current study belongs to the topic of digital games on the global level and its contribution to the learning process with the increase in the global trend of using technology, the Internet and digital games. The use of games could be one of the strategies to improve students' motivation, cognitive abilities, and performance [13]. Consequently, the current study will reveal the contribution of digital learning games to the development of many aspects of the learning process through legalization the Digital Learning Games Scale (DLGS) from the perspective of primary school teachers in Palestine.

Many studies have shown that digital learning games improve the learning process in many aspects [14-15]. However, some teachers are hesitant to use them for many reasons [16], so it was important to legalize a scale that determines teachers' responses towards the contribution of digital learning games to improving the learning process in many aspects due to the lack of clear standards in the Palestinian context to measure the contribution of digital learning game. The current study will legalize a scale with different dimensions and paragraphs about digital learning games to measure the most important aspects of the learning process and to be adopted and used in the future as a measurement tool to conduct studies related to digital learning games in the learning process.

The current study aims to legalize a measure for digital learning games and to reveal the most important factors that explain the contribution of digital learning games to the learning process in addition to reveal the degree of contribution of digital learning games to the learning process from the perspective of elementary school teachers in Palestine. The study will try to answer the following questions: 
1. What are the factors of digital learning games scale in the learning process from the perspective of elementary school teachers in Palestine?

2. What are the factors most contributing to the interpretation of the digital learning games scale in the learning process from the perspective of elementary school teachers in Palestine?

3. What is the level of the contribution of digital learning games to the learning process from the perspective of elementary school teachers in Palestine?

\section{$2 \quad$ Literature Review}

\subsection{Digital learning games}

With the rapid advancement of technology, the concept of the traditional game has changed, and a new concept has been created which is the digital game with the fact that digital tools has become an indispensable part in everyday life [17]. Digital learning games are games that are programmed with many technologies that enable learners to $\log$ in with a visual environment. It is necessary to distinguish between computer games or video games and digital games that are integrated into the educational system (DGBL - Digital Games Based Learning). Learning based on digital games links the educational content to the capabilities of the computer. The teacher can use the digital learning games that are appropriate for the learners and for the content, in a way that leads to achievement of the intended learning goals.

\subsection{The contribution of digital learning games to the learning process}

The main role of digital games is to motivate students towards learning, and to enhance the learning process through challenge, exploration, interaction and decisionmaking, whether it is learning individually or in groups, which leads to creating a unique learning environment in which students interact [18]. The digital game is an effective tool for improving short-term learning achievement, therefore there are a number of features and characteristics required to make a digital game effective: the subject, design, game characteristics, nature of knowledge dissemination [18]. It is inevitable that digital learning games are reflected in education. Therefore, different studies have been conducted to use digital learning games. Tokarieva et al. [20] demonstrated that digital learning games play a major role in stimulating students' motivation towards learning, providing more original learning and teaching different thinking skills and employing cooperative learning based on problem solving.

Digital games are effective in learning because they stimulate, encourage cooperation, and they are suitable for a variety of learning styles, which require solving problems and providing feedback. Immediately requires planning and encouraging multiple attempts without fear of failure, many studies have indicated different benefits of integrating digital learning games such as enjoyment, contentment, challenge, shared learning, increased academic achievement, creativity, active learning, satisfaction and social opportunity ([21-22]. The advantages of digital games are not limited to the 
content of knowledge and motivation of the drive towards learning, but it includes many skills and opportunities for computer literacy. Furdu, et al. [23] confirmed that the use of educational digital games gives the learner an opportunity to develop his technological skill, the trend towards modernity, challenge and curiosity, which helps him to be a self-learner responsible for his learning, the use of digital games stimulates also the learners' imaginations and helps them to develop their skills such as writing skills, coordinating the work of their senses, and enhancing logical thinking. It also stimulates neurons in their brains and encourages the spirit of cooperation with others and making friendships.

\subsection{Integrating digital learning games in education}

Digital learning games can be integrated with other learning methods and provide a complete learning. Digital games are classified in many categories. These categories mainly consist of abstract games, meaningless games, meaningful games, and progressive games. There is no limit to the possibilities of integrating digital games with learning. There are teachers who prefer to incorporate the game as an introduction to their lesson, others are at the middle of the lesson and some prefer to finish the lesson with a game. The game can be integrated into the lesson inside or outside the classroom. Also, there are teachers who develop games themselves, some of them are still in the process of developing this area, and others are asking learners to develop games themselves and play with them [24].

Games allow participants to form common goals, and share their experiences and knowledge, which helps them to remember many contents of the materials and subjects by stimulating discussion among them, experiment and make mistakes that aim to help them to learn and enable the content of knowledge. Also, digital learning games allow the creation of open societies for students, whether they are beginners or mature, allowing them to set common goals, and share their experiences and knowledge with other students, they also help students to remember the materials by stimulating discussion among them, making mistakes that help to learn and enable the content of knowledge showed. Digital learning games also help to stimulate students' motivation towards learning as they are very effective for creating work that is usually boring or less challenging to become more fun and interesting. They also support the learning process by transforming routine tasks into more motivating. The features of digital games focus on encouraging student participation and increasing their interest in the learning process, they develop physical skills and cognitive mental processes, they also increase the interest of students towards the courses integrated school and non-school life through creating a dynamic environment in which learners feel a sense of progress. It makes learning not only informative, but fun and exciting too. Tokarieva et al [20] demonstrated that many scholar topics are difficult to understand within the traditional strategy of education, so the teacher can use a digital game that explains the subject in a simple and enjoyable way to understand. 


\subsection{The dimensions of digital learning games scale}

The digital games contribute to the development of many skills in the learning process in several areas: communication, developing thinking skills, acquiring knowledge, motor skills, psychodynamic ability, and developing the social and therapeutic field in terms of improving physical and mental health [24]. Figure (1) shows the dimensions of Digital Games Learning Scale developed in this study.

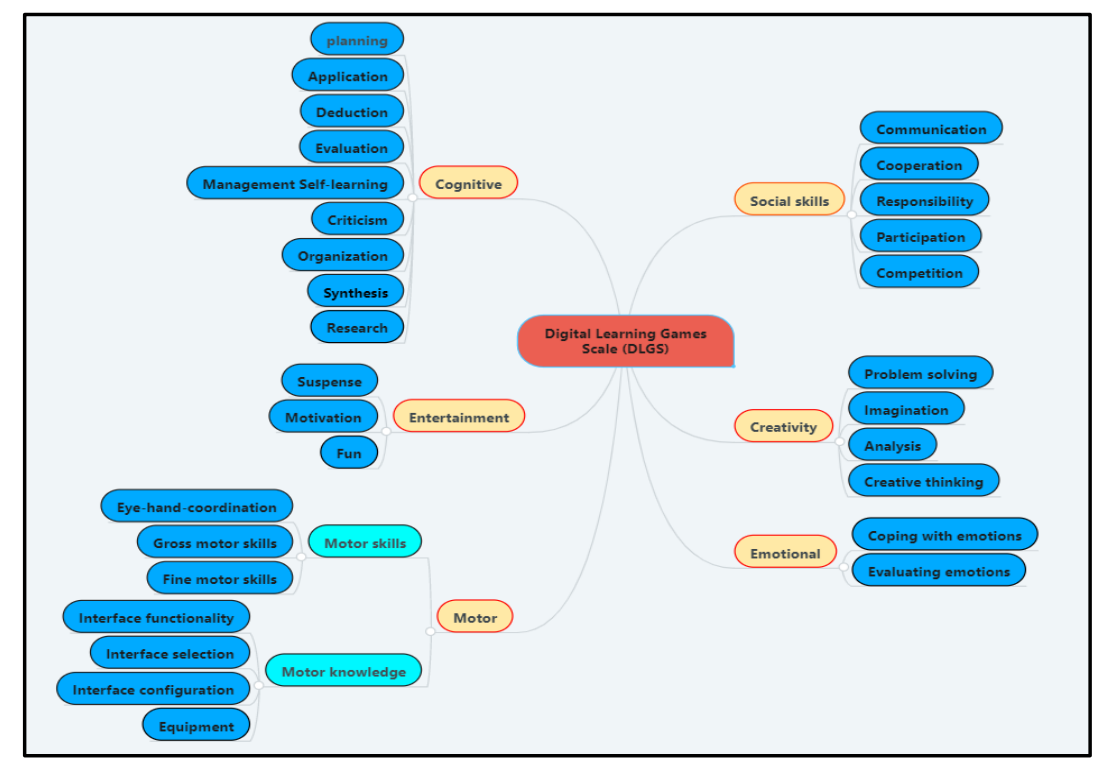

Fig. 1. The dimensions of digital learning games scale (DLGS)

Development of social skills: The use of digital learning games is a powerful learning tool as the learner is encouraged to participate, improve performance and stimulate the generation of individual, collective, and social experiences. Digital games promote genuine collaboration between learners, and are, to some extent, similar to collaborative learning environments, where participants share information and learn from each other. Multiplayer digital games develop both competition and collaboration, by motivating players to join teams (or guilds) and to compete against other teams. players can create teams, share information through text and voice and learn by observing other players. Beginners can learn from their peers and improve their skills [25].

Development of mental cognitive processes: The digital game contributes to the acquisition of knowledge and the creation of new knowledge, it helps to sustain the information and retrieving it from memory due to practice and repetition, the Information is stored in memory for a longer period [15]. It also contributes to developing the skills of planning, application, synthesis, evaluation, organization, deduction, research, criticism and management of the self-learning process [18]. Digital learning games develop many mental skills during the learning process. 
Learning with fun and entertainment: The primary goal of digital learning games is to educate the individual and give him more knowledge and skills; but at the same time the digital games are a form of entertainment and fun that increase motivation, and suspense of the learner [26].

Development of emotional affective skills: Emotional skills include dealing with emotions: The immersive character of the computer and the video games, success and disappointment, handling pressure and nerves and flow, anger, empathy, joy, frustration or triumph and evaluating emotions: the question whether disappointment in the digital game affects disappointment in the real life, mood management which allows identification of specific games or parts of games as the cause of good or bad emotion [27].

Stimulating creativity: Game design has been emphasized as a very useful context for the development of the digital creative thinking, and the learner will be able to discover many solutions to problems in a creative way, through imagination and analysis, and opening up new opportunities for him to engage with meaningful learning experiences which can translate into more sustainable practices in real world [28].

Development of motor skills: Digital games help to develop motor skills and motor knowledge in the learning process: Motor skills include sensorimotor coordination embracing eye-hand-coordination such as screen action in coordination with mouse/keyboard/ steering wheel and gross motor skills such as upper body and arm movement using a steering wheel, following and imitating the movement of the controlled character on the screen, and the fine motor skills : using keyboard, mouse, steering wheel and accelerator pedal the motor knowledge includes user interface functionality such as labeling buttons and controller directions using controller specific terms and user interface selection such as selecting mouse or keyboard according to game efficiency, user interface configuration such as individual configuration of joypad according to game efficiency and individual preferences, and equipment that includes knowing technical equipment dealing with the game and platform [29].

\section{$3 \quad$ Methodology}

\subsection{Participants}

The study participants consisted of 280 Palestinian teachers working in elementary schools in 2020-2021 academic year. The study sample was selected by taking a random sample.

The descriptive statistics of the questionnaire items are given in Table 1. 
Table 1. Means, standard deviations and skewness of the scale items $(\mathrm{N}=280)$

\begin{tabular}{|c|c|c|c|}
\hline Items & $\mathbf{M}$ & SD & Skew \\
\hline $\begin{array}{l}\text { Digital learning games increase the chance of building new friendships for } \\
\text { the student. }\end{array}$ & 3.33 & 1.02 & -0.67 \\
\hline Digital learning games increase the student's chances of social adjustment. & 3.05 & 1.10 & -0.30 \\
\hline Digital learning games increase the student's social maturity & $\mathbf{3 . 0 3}$ & 1.10 & -0.32 \\
\hline Digital learning games lead to the acquisition of new values for the student. & 3.35 & 1.03 & -0.55 \\
\hline $\begin{array}{l}\text { Digital learning games provide the student with interaction with colleagues } \\
\text { while playing. }\end{array}$ & 3.67 & 0.87 & -1.24 \\
\hline $\begin{array}{l}\text { Digital learning games are useful in teaching students ethical societal val- } \\
\text { ues. }\end{array}$ & 3.13 & 1.05 & -0.18 \\
\hline The student learns to cooperate while playing. & 3.45 & 1.00 & -0.77 \\
\hline The student learns the ways of distributing roles while playing. & 3.67 & $\mathbf{0 . 8 3}$ & -0.16 \\
\hline $\begin{array}{l}\text { Digital learning games enhance the student's interaction with the read in- } \\
\text { structions. }\end{array}$ & 2.94 & 1.14 & 0.01 \\
\hline $\begin{array}{l}\text { Digital learning games develop in the student self-control in dealing with } \\
\text { others. }\end{array}$ & 3.13 & 1.02 & -0.26 \\
\hline Digital learning games develop the evaluation skill of the student & 3.51 & 0.90 & -0.68 \\
\hline Digital learning games develop the student's installation skill. & 3.72 & 0.81 & -1.09 \\
\hline Digital learning games develop the student's application skill. & 3.72 & 0.85 & -1.12 \\
\hline Digital learning games develop the student's planning skill. & 3.55 & 0.90 & -0.77 \\
\hline $\begin{array}{l}\text { Digital learning games contribute to the student's development of organized } \\
\text { thinking. }\end{array}$ & 3.64 & 0.89 & -0.83 \\
\hline $\begin{array}{l}\text { Digital learning games contribute to recalling mental images that represent } \\
\text { previous events and experiences that the student has gone through. }\end{array}$ & 3.64 & 0.77 & -0.96 \\
\hline Digital learning games develop students' logic skills & 3.59 & 0.89 & -0.65 \\
\hline Digital learning games develop the student's deduction skill. & 3.53 & 0.89 & -0.62 \\
\hline $\begin{array}{l}\text { Digital learning games provide the student with an atmosphere of } \\
\text { pleasure in the educational environment. }\end{array}$ & 3.99 & 0.76 & -1.24 \\
\hline Digital learning games increase the student's learning motivation. & 3.8 & 0.85 & -0.93 \\
\hline $\begin{array}{l}\text { Digital learning games increase the chances of fun during the retry of learn- } \\
\text { ing. }\end{array}$ & 3.93 & 0.78 & -1.02 \\
\hline $\begin{array}{l}\text { Digital learning games use fun sensory stimuli that make learning last } \\
\text { longer. }\end{array}$ & 3.64 & 0.88 & -0.49 \\
\hline Digital learning games reduce a student's traditional learning routine. & 3.98 & 0.73 & -1.09 \\
\hline Availability of Digital learning games; instant fun feedback for the student. & 3.73 & 0.88 & -0.81 \\
\hline Digital learning games provide the fun of self-learning. & 3.82 & 0.82 & -1.12 \\
\hline Digital learning games save time and effort in learning & 3.54 & 0.99 & -0.68 \\
\hline Digital learning games provide sequential educational content. & 3.42 & 0.89 & -0.46 \\
\hline Digital learning games provide the student with experiences close to reality. & 3.61 & $\mathbf{0 . 8 5}$ & -0.57 \\
\hline $\begin{array}{l}\text { Digital learning games provide a pleasant emotional experience for the } \\
\text { student, especially when he wins the challenge. }\end{array}$ & 4.12 & 0.68 & -0.99 \\
\hline $\begin{array}{l}\text { Play contributes to teaching the student order and adherence to rules and } \\
\text { laws. }\end{array}$ & 3.64 & 0.86 & -0.91 \\
\hline $\begin{array}{l}\text { The student acquires, through Digital learning games, new ways to solve } \\
\text { problems. }\end{array}$ & 3.67 & 0.83 & -0.75 \\
\hline $\begin{array}{l}\text { Digital learning games develop self-reliance and independence for the } \\
\text { student. }\end{array}$ & 3.52 & 0.92 & -0.65 \\
\hline $\begin{array}{l}\text { Digital learning games reduce the feeling of excessive shyness for some } \\
\text { students. }\end{array}$ & 3.34 & 1.04 & $-\mathbf{0 . 5 0}$ \\
\hline Digital learning games contribute to strengthening & 3.15 & 1.05 & $-\mathbf{0 . 3 2}$ \\
\hline
\end{tabular}




\begin{tabular}{|c|c|c|c|}
\hline Digital learning games enhance student's confidence. & 3.31 & 0.97 & -0.58 \\
\hline $\begin{array}{l}\text { Playing reduces the student's excess energy by venting his emotions through } \\
\text { play. }\end{array}$ & 3.44 & 1.02 & -0.81 \\
\hline Digital learning games help improve students' nervous maturity. & 3.14 & 1.04 & -0.17 \\
\hline Digital learning games develop the student's imagination skill. & 3.79 & 0.89 & -0.95 \\
\hline Digital learning games develop the skill of creative thinking. & 3.62 & 0.96 & -0.77 \\
\hline Digital learning games develop the student's problem-solving skill & 3.53 & 0.97 & -0.65 \\
\hline Digital learning games develop the student's analytical skill. & 3.60 & 0.91 & -0.64 \\
\hline Digital learning games provide synergy for the student's sense of movement. & 3.50 & 0.93 & -0.58 \\
\hline Digital learning games enhance synergy between hand and eye movements. & 3.81 & 0.84 & -1.09 \\
\hline $\begin{array}{l}\text { Digital learning games provide muscle coordination with the student's } \\
\text { senses. }\end{array}$ & 3.38 & 0.97 & -0.61 \\
\hline Digital learning games develop the student's speed of movement. & 3.53 & 0.96 & -0.59 \\
\hline $\begin{array}{l}\text { Digital learning games lead to the efficient distribution of visual attention of } \\
\text { the student. }\end{array}$ & 3.45 & 0.92 & -0.75 \\
\hline $\begin{array}{l}\text { Digital learning games provide the student with an opportunity to freely } \\
\text { express his emotions. }\end{array}$ & 3.54 & 0.92 & -0.66 \\
\hline
\end{tabular}

\subsection{Measurement tool}

In the first phase of the process of developing the "contribution of Digital learning games scale", a literature review was conducted about digital learning games (e.g., [911]). As a result of literature reviews, dimensions that can best measure the contribution of digital learning games have been tried to determine and, in this direction, a pool of 71 items has been established. In the second phase, the draft scale was reduced to 65 items as a result of the elimination of the items that were not related to the dimensions that were based on the research, or which were estimated to have a low relationship and screening between similar expressions. In the third phase, the opinion of field experts was taken about the validity and appearance of the measuring instrument. In this context, five faculty members who are experts in the field of educational sciences were consulted to express an opinion. After expert examination, the number of items was reduced to 61 with the expressions organized on the aforementioned scale. In the fourth phase, in order to ensure the comprehensibility of the measuring instrument in terms of language, the opinion of an expert in Arabic language and literature was consulted.

In line with the opinions on spelling rules and the use of punctuation marks, the scale items have been reviewed. Finally, without any dimensioning on the draft scale, the 61 items were added to the scale to obtain personal information about the participants with a directive explaining the purpose of the study and the answers expected from the participants. The draft scale prepared for implementation is called Digital Learning Games Scale (DLGS). The scale, which was designed to determine the responses of the participants with the Likert-type five-point rating consisted of strongly disagree (1), disagree (2), neutral (3), agree (4), and strongly agree (5) options. We computed the "neutral score ", the range is $(5-1=4)$ then they divide 4 by 5 (where number one is the lowest score of any item, and number five is the highest). $(4 \div 5=$ 0.80 ) which was used to find intervals on a scale presented in Figure 2. We considered point (1.8) to be a 'disagree score', (2.6) to be a 'neutral score' and (3.4) to be a 
'agree score' on this scale. Thus, the scores between (1) and (1.8) were considered 'strongly disagree scores', the scores between (1.8) and (2.6) 'disagree scores', the scores between (2.6) and (3.4) 'neutral scores', the scores between (3.4) and (4.2) 'agree scores', and the scores between (4.2) and (5) 'strongly agree scores.

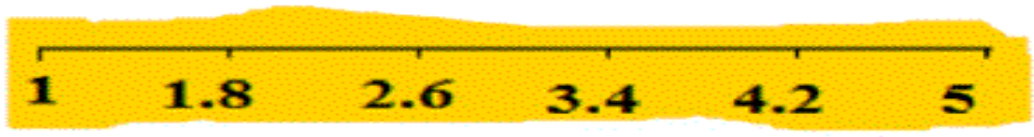

Fig. 2. Intervals related to the contribution of Digital learning games scores of any item

To determine whether questions on the draft scale were understood by teachers, a pilot study was conducted into a group of 70 teachers. In this application, there was no criticism by the teachers of the pre-application of the items on the scale, and it was stated that the items were quite understandable. Thus, the final form of the draft scale is given.

\subsection{Research method}

In order to determine the validity and reliability of the measurement tool, questionnaire was applied to 280 teachers employed in elementary schools in Palestine in the 2020-2021 academic year, the scale was distributed and assembled by the researchers in an electronic way, the number of scales to be analyzed was determined as 280 . After the data was obtained, statistical analyses were carried out to reveal the psychometric properties of the measurements. Therefore, the appropriate sample group and number should be determined. In the literature, there are opinions that suggest that the number of people to be applied in relation to the number of items in the scale, which can also be expressed as sample size, be determined. Some authors consider it sufficient for the number of people to be applied to be at least five times the number of items on the scale but according to the specified criteria, it can be said that the number of participants in the research group is sufficient for factor analysis [30].

\subsection{Validity and reliability analysis}

To do the validity and reliability analyses, we followed Daher [31]. Here these analyses were performed for the six dimensions. To ensure validity, the first-version of the scale has been examined by (5) experts working in educational sciences institutes, to analyze it and verify its validity for data collection. Thus, the number of items has been reduced, and the necessary corrections were made to the scale, which gave the present 47 -item, and have been designed in the 5-point Likert type scale. To ensure reliability, Cronbach's Alpha was found for each of the six factors.

This computation gave .86 for the development of participatory social skills, .85 for the development of cognitive mental processes, .87 for learning with fun and entertainment, .85 for development of emotional affective skills, .79 for stimulating creativity, .81 for sensory-motor skills. These reliability results indicate good reliabil- 
ity for the constructs: the development of participatory social skills, the development of cognitive mental processes, learning with fun and entertainment, development of emotional affective skills, stimulating creativity, sensory-motor skills because these reliabilities are around .80 [32]. The Cronbach Alpha computation for the total scale is .914 which indicates high reliability.

\section{$4 \quad$ Results}

\subsection{What are the factors of digital learning games scale in the learning process} from the perspective of elementary school teachers in Palestine?

Exploratory factor analysis was used to answer the first question by determine whether the scale which is composed of 47 items, is single or multi-factor. Accordingly, principal components analysis and varimax rotation method were used. The appropriateness of the correlation matrix for factor analysis was established using the Kaiser-Meyer-Oklin (KMO) test of sampling adequacy and the Bartlett test of Sphericity (BS). To determine the reliability status of the scale, Cronbach's alpha value, which determines the internal consistency measure, and item total correlations were examined.

At first, the factorability of the 47 digital learning games items was examined. The data was sifted for factorability using several well recognized criteria. Initially, all the items were correlated at least 0.3 with at least one other item, indicating reasonable factorability, and $\mathrm{KMO}$ value measure of sampling adequacy was found .928 , above the commonly recommended value of .6, and Bartlett's test of sphericity result was significant $\left(\chi^{2}(1830)=9075.35, p<.000\right)$. The diagonals of the anti-image correlation matrix were also all over .5 , the communalities were all above .40 , further confirming that each item shared some common variance with other items. Given these overall indicators, factor analysis was deemed to be suitable with all 47 items. Factor loadings based on rotated principal components analysis with varimax rotation for 47 items from the above scale $(\mathrm{N}=280)$ are presented in table (2), varimax rotation method was used to give a better picture of factors in this analysis. 
Table 2. Factor loadings based on varimax -rotated principal components analysis $(\mathrm{N}=280)$

\begin{tabular}{|c|c|c|c|c|c|c|}
\hline \multirow{2}{*}{ Item } & \multicolumn{6}{|c|}{ Component } \\
\hline & 1 & 2 & 3 & 4 & 5 & 6 \\
\hline $\begin{array}{l}\text { Digital learning games increase the chance of building new friend- } \\
\text { ships for the student. }\end{array}$ & 0.79 & & & & & \\
\hline $\begin{array}{l}\text { Digital learning games increase the student's chances of social ad- } \\
\text { justment. }\end{array}$ & 0.77 & & & & & \\
\hline Digital learning games increase the student's social maturity & 0.76 & & & & & \\
\hline $\begin{array}{l}\text { Digital learning games lead to the acquisition of new values for the } \\
\text { student. }\end{array}$ & 0.64 & & & & & \\
\hline $\begin{array}{l}\text { Digital learning games provide the student with interaction with } \\
\text { colleagues while playing. }\end{array}$ & 0.62 & & & & & \\
\hline $\begin{array}{l}\text { Digital learning games are useful in teaching students ethical societal } \\
\text { values. }\end{array}$ & 0.60 & & & & & \\
\hline The student learns to cooperate while playing. & 0.58 & & & & & \\
\hline The student learns the ways of distributing roles while playing. & 0.53 & & & & & \\
\hline $\begin{array}{l}\text { Digital learning games enhance the student's interaction with the read } \\
\text { instructions. }\end{array}$ & 0.52 & & & & & \\
\hline $\begin{array}{l}\text { Digital learning games develop in the student self-control in dealing } \\
\text { with others. }\end{array}$ & 0.51 & & & & & \\
\hline Digital learning games develop the evaluation skill of the student & & 0.74 & & & & \\
\hline Digital learning games develop the student's installation skill. & & 0.74 & & & & \\
\hline Digital learning games develop the student's application skill. & & 0.72 & & & & \\
\hline Digital learning games develop the student's planning skill. & & 0.68 & & & & \\
\hline $\begin{array}{l}\text { Digital learning games contribute to the student's development of } \\
\text { organized thinking. }\end{array}$ & & 0.61 & & & & \\
\hline $\begin{array}{l}\text { Digital learning games contribute to recalling mental images that } \\
\text { represent previous events and experiences that the student has gone } \\
\text { through. }\end{array}$ & & 0.59 & & & & \\
\hline Digital learning games develop students' logic skills & & 0.59 & & & & \\
\hline Digital learning games develop the student's deduction skill. & & 0.54 & & & & \\
\hline $\begin{array}{l}\text { Digital learning games provide the student with an atmosphere of fun } \\
\text { and pleasure in the educational environment. }\end{array}$ & & & 0.83 & & & \\
\hline Digital learning games increase the student's learning motivation. & & & 0.73 & & & \\
\hline $\begin{array}{l}\text { Digital learning games increase the chances of fun during the retry of } \\
\text { learning. }\end{array}$ & & & 0.71 & & & \\
\hline $\begin{array}{l}\text { Digital learning games use fun sensory stimuli that make learning last } \\
\text { longer. }\end{array}$ & & & 0.67 & & & \\
\hline Digital learning games reduce a student's traditional learning routine. & & & 0.63 & & & \\
\hline $\begin{array}{l}\text { Availability of digital learning games; instant fun feedback for the } \\
\text { student. }\end{array}$ & & & 0.62 & & & \\
\hline Digital learning games provide the fun of self-learning. & & & 0.56 & & & \\
\hline Digital learning games save time and effort in learning & & & 0.54 & & & \\
\hline Digital learning games provide sequential educational content. & & & 0.53 & & & \\
\hline $\begin{array}{l}\text { Digital learning games provide the student with experiences close to } \\
\text { reality. }\end{array}$ & & & 0.46 & & & \\
\hline $\begin{array}{l}\text { Digital learning games provide a pleasant emotional experience for } \\
\text { the student, especially when he wins the challenge. }\end{array}$ & & & 0.45 & & & \\
\hline $\begin{array}{l}\text { Play contributes to teaching the student order and adherence to rules } \\
\text { and laws. }\end{array}$ & & & 0.44 & & & \\
\hline
\end{tabular}




\begin{tabular}{|c|c|c|c|c|}
\hline $\begin{array}{l}\text { The student acquires, through digital learning games, new ways to } \\
\text { solve problems. }\end{array}$ & 0.43 & & & \\
\hline $\begin{array}{l}\text { Digital learning games develop self-reliance and independence for the } \\
\text { student. }\end{array}$ & & 0.69 & & \\
\hline $\begin{array}{l}\text { Digital learning games reduce the feeling of excessive shyness for } \\
\text { some students. }\end{array}$ & & 0.65 & & \\
\hline $\begin{array}{l}\text { Digital learning games contribute to strengthening the student's } \\
\text { personality. }\end{array}$ & & 0.60 & & \\
\hline Digital learning games enhance student's confidence. & & 0.60 & & \\
\hline $\begin{array}{l}\text { Playing reduces the student's excess energy by venting his emotions } \\
\text { through play. }\end{array}$ & & 0.44 & & \\
\hline Digital learning games help improve students' nervous maturity. & & 0.42 & & \\
\hline Digital learning games develop the student's imagination skill. & & & 0.66 & \\
\hline Digital learning games develop the skill of creative thinking. & & & 0.63 & \\
\hline Digital learning games develop the student's problem-solving skill & & & 0.60 & \\
\hline Digital learning games develop the student's analytical skill. & & & 0.55 & \\
\hline $\begin{array}{l}\text { Digital learning games provide synergy for the student's sense of } \\
\text { movement. }\end{array}$ & & & & 0.70 \\
\hline $\begin{array}{l}\text { Digital learning games enhance synergy between hand and eye } \\
\text { movements. }\end{array}$ & & & & 0.65 \\
\hline $\begin{array}{l}\text { Digital learning games provide muscle coordination with the student's } \\
\text { senses. }\end{array}$ & & & & 0.60 \\
\hline Digital learning games develop the student's speed of movement. & & & & 0.59 \\
\hline $\begin{array}{l}\text { Digital learning games lead to the efficient distribution of visual } \\
\text { attention of the student. }\end{array}$ & & & & 0.52 \\
\hline $\begin{array}{l}\text { Digital learning games provide the student with an opportunity to } \\
\text { freely express his emotions. }\end{array}$ & & & & 0.44 \\
\hline
\end{tabular}

The principal component analysis (PCA) was used to bring out strong patterns in a dataset and Initial eigenvalues indicated that the first six factors explained: social skills $(23.52 \%)$, cognitive mental processes $(3.89 \%)$, learning with fun and entertainment $(2.59 \%)$, emotional affective $(2.32 \%)$, stimulating creativity $(1.80 \%)$ and sensory-motor skills development $(1,54 \%)$ of the variance.

Our adoption of the sixth- dimensions model depended on the results of the principal factor analysis, including the total-variance-explained table and the scree plot (see Figure 3 below). According to the solution, the six dimensions explained (68.38\%) of the variance in the contribution of digital learning games scores, and this percentage is considered acceptable in social science Studies [32]. 


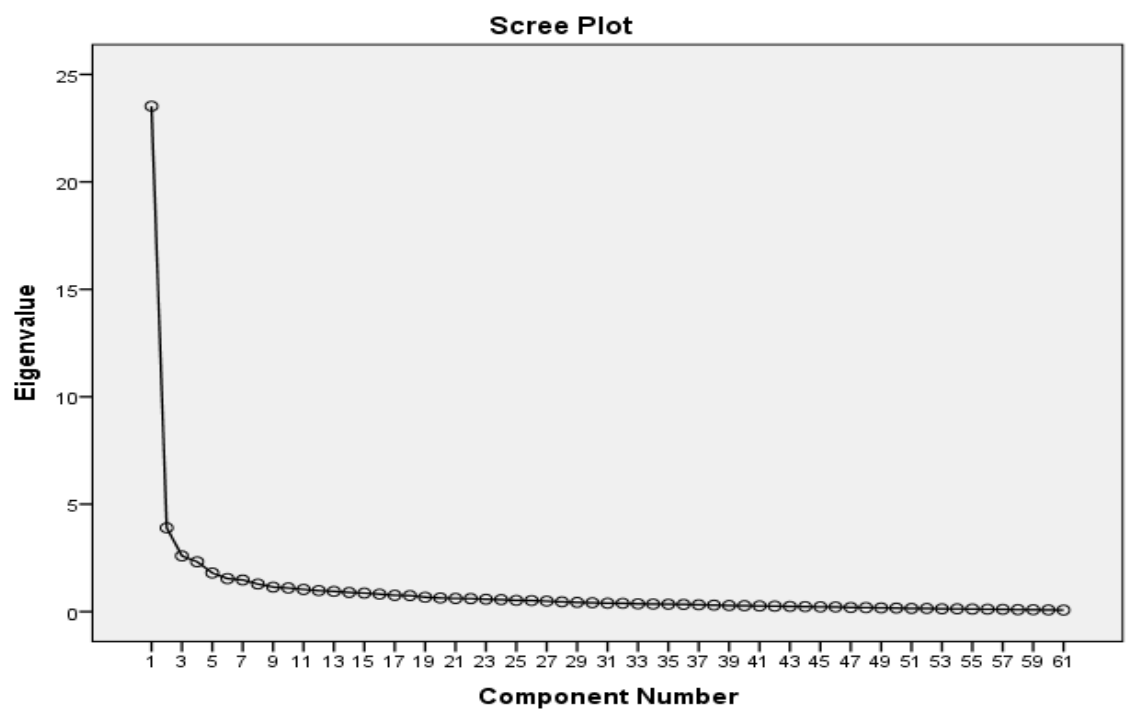

Fig. 3. Scree Plot of the items' factorization

As One can see from Figure (3) the result of the factor analysis; the eigen value of which is 1 , shows that the number of the dimensions of the scale is six, five dimensions were removed from the analysis.

4.2 What are the factors most contributing to the interpretation of the digital learning games scale in the learning process from the perspective of elementary school teachers in Palestine?

Regression analysis: A stepwise linear regression analysis was performed for the dimensions of contribution of Digital learning games, this step involves the selection of independent variables to be used in a final model. It involves adding or removing potential explanatory variables in succession and testing for statistical significance after each iteration. 
Table 3. Results of stepwise linear regression analysis, under specification of standardized beta coefficient, $\alpha=.05$ )

\begin{tabular}{|c|c|c|c|c|c|c|}
\hline Dimensions & Model 1 & Model 2 & Model 3 & Model 4 & Model 5 & Model 6 \\
\hline Learning with fun and entertainment & 0.86 & 0.55 & 0.35 & 0.31 & 0.31 & 0.29 \\
\hline $\begin{array}{l}\text { Learning with fun and entertainment, the } \\
\text { development of participatory social skills }\end{array}$ & & 0.50 & 0.42 & 0.32 & 0.33 & 0.28 \\
\hline $\begin{array}{l}\text { Learning with fun and entertainment, the } \\
\text { development of participatory social skills, } \\
\text { the development of cognitive mental } \\
\text { processes }\end{array}$ & & & 0.34 & 0.33 & 0.32 & 0.30 \\
\hline $\begin{array}{l}\text { Learning with fun and entertainment, the } \\
\text { development of participatory social skills, } \\
\text { the development of cognitive mental } \\
\text { processes, development of emotional } \\
\text { affective skills. }\end{array}$ & & & & 0.18 & 0.20 & 0.18 \\
\hline $\begin{array}{l}\text { Learning with fun and entertainment, the } \\
\text { development of participatory social skills, } \\
\text { the development of cognitive mental } \\
\text { processes, development of emotional } \\
\text { affective skills, sensory-motor skills devel- } \\
\text { opment }\end{array}$ & & & & & 0.09 & 0.10 \\
\hline $\begin{array}{l}\text { Learning with fun and entertainment, the } \\
\text { development of participatory social skills, } \\
\text { the development of cognitive mental } \\
\text { processes, development of emotional } \\
\text { affective skills, sensory-motor skills devel- } \\
\text { opment, stimulating creativity. }\end{array}$ & & & & & & 0.14 \\
\hline $\mathrm{R}^{2}$ & 0.748 & 0.904 & 0.959 & 0.970 & 0.979 & 0.987 \\
\hline
\end{tabular}

Only coefficients with statistically significances at the $\mathrm{P}<0.05$ level were reported

Table (3) shows the stepwise regression analysis of the contribution of Digital learning games to the learning process, A model with 6 steps was carried out and explained more than $80 \%\left(\mathrm{r}^{2} \sim 0.80\right)$ of the variance on the dependent variable 'total mean'. Within the stepwise regression analysis, the factor 'learning with fun and entertainment' $(\beta=0.86)$ showed the highest association to overall factors. Figure (4) illustrates the residuals from the regression line fit to the data. the plot shows that, for large observed values of the dependent variable, the predictions are smaller than the observed values, with an opposite trend for the small observed values of the dependent variable. 


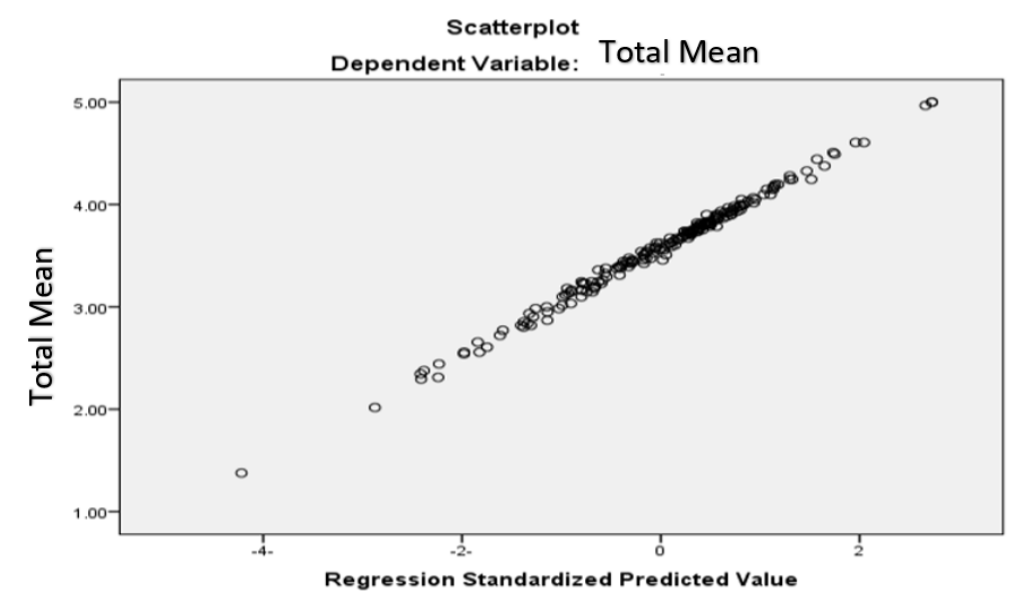

Fig. 4. Regression Standardized Predicted Values Plotted of the contribution of Digital learning games to the learning process

\subsection{What is the level of the contribution of digital learning games to the learning process from the perspective of elementary school teachers in Palestine?}

To assess the level of contribution of digital learning games scores in the Palestinian schools, we computed means and standard deviations for the six dimensions: the development of participatory social skills, the development of cognitive mental processes, learning with fun and entertainment, development of emotional affective skills, stimulating creativity, sensory-motor skills development.

We also conducted a one-sample $t$-test to assess the statistical significance of the variation of each factor with a disagree, neutral and agree level of contribution of digital learning games (see Table 4). To calculate the contribution of digital learning games mean scores for the teachers participating in the research, the researchers computed first grouped frequency distributions [33]. Then we compared the resulting of the contribution of Digital learning games mean scores with a 'agree score' and a 'neutral score'. 
Table 4. Level of contribution of digital learning games scores in the Palestinian schools $(\mathrm{N}=280), * * \mathrm{p}<.000$

\begin{tabular}{|c|c|c|c|c|}
\hline \multicolumn{2}{|c|}{} & \multicolumn{3}{|c|}{ T value } \\
\hline Component & $\boldsymbol{M}(\boldsymbol{S D})$ & Disagree & Neutral & Agree \\
\hline 1 & $3.27(0.78)$ & $12.23^{* *}$ & $2.25^{* *}$ & $-16.74^{* *}$ \\
\hline 2 & $3.61(0.69)$ & $20.54^{* *}$ & $4.33^{* *}$ & $-11.88^{* *}$ \\
\hline 3 & $3.76(0.60)$ & $27.19^{* *}$ & $8.48^{* *}$ & $-10.24^{* *}$ \\
\hline 4 & $3.32(0.81)$ & $12.53^{* *}$ & $-1.46^{* *}$ & $-15.44^{* *}$ \\
\hline 5 & $3.64(0.78)$ & $18.89^{* *}$ & $4.34^{* *}$ & $-10.21^{* *}$ \\
\hline 6 & $3.54(0.71)$ & $18.53^{* *}$ & $2.69^{* *}$ & $-11.16^{* *}$ \\
\hline Total & $3.57(0.52)$ & $26.47^{* *}$ & $4.76^{* *}$ & $-16.94^{* *}$ \\
\hline
\end{tabular}

The results show that the p-value (.000) is less than .05 , the of contribution of digital learning games scores in the Palestinian schools is significantly different from 4.2 .

\section{Discussion}

Globalization and advanced technology have opened many new learning opportunities [34]. Education systems must prepare learners for an unknown and indeterminate world, in which they need diverse skills and tools that enable the learner to be immersed in it [35-36].

Therefore, this study aimed to develop a valid and reliable measurement tool for contribution of digital learning games to the learning process. The scale was prepared as a five-point Likert type. The scale, which consisted of 61 items as a draft, was applied to a total of 280 teachers.

The results of the KMO and BS tests were examined before EFA was performed and it was concluded that the data was suitable for EFA as a result of the KMO value being less than .936 and $\mathrm{BS}$ value being less than $\mathrm{p}<.05$.In order to determine the construct validity of the digital learning scale, 4 items were excluded from the scale after Exploratory factor analysis was applied, and the result of EFA showed that there are seven factors which explained $(68.38 \%$ ) of the variance of Digital learning games scores. In the next stage of the stepwise regression analysis showed a model with 6 steps explained more than $80 \%\left(\mathrm{r}^{2} \sim 0.80\right)$ of the variance on the dependent variable 'total mean (one factor with six items were excluded)'. And these factors are: the development of participatory social skills, the development of cognitive mental processes, learning with fun and entertainment, development of emotional affective skills, stimulating creativity, sensory-motor skills development.

These factors are the most important factors that explain the contribution of digital learning games to the learning process from perspective of elementary school teachers in Palestine. The digital games can develop the participatory and social skills; the learner can cooperate with others and share propositions and ideas about the game and can be social and respect others when sharing learning ([14], [21]). When the learner plays and repeat the digital game many times in order to win and to have more scores; he can learn more and more in entrainment way which lead to achieving the learning goals [26]. Thus, it aims to provide more intense of gravity, interactions and experiences and engaging learners in a fun way. In the dimension of stimulating creativity, 
the digital games help to stimulate the creative thinking of learners and develop skills in solving problems and collaborative learning [11].

The digital games help develop the student's ability to retrieve, analyze, synthesize, apply, and evaluate which reflects the mental cognitive processes at their various levels; the learner can employ his mental cognitive processes and develop them through repetition and practice. Chen et al. [19] in a way that help improve coordination and movement that reflects the sensory-motor skills of the learner [29]. In addition to the emergence of different feelings and emotions during the game in line with the content of the game and the progress achieved [27]. The contribution of digital learning games to the learning process was confirmed in the result of the third question, which showed a very high level of contribution of digital games to learning process from the perspective of elementary school teachers who think that digital games create a dynamic environment through achieving levels, and positive outcomes like self-fulfillment and a sense of achievement which enhance and sustain intrinsic motivation, the digital games help also learners to increase attention and focus during narrative activities, puzzles and competitions, and helps them to acquire the skill of self-learning, and works to develop the learner's ability to imagine and innovate ,thus ; the Digital learning games have many advantages and benefits in the learning process , they contribute to many aspects in the learning process if they are integrated and used in a correct and effective way, which led to a very high level in teachers 'response to the current scale.

\section{Conclusion and Recommendations}

Digital learning games contribute to the development of many dimensions in the learning process from the perspective of teachers who participated in the current study. According to the results of the study, the researchers recommend to use the current scale of digital learning games (DLGS) that resulted from the current study with the six dimensions: the development of participatory social skills, the development of cognitive mental processes, learning with fun and entertainment, development of emotional affective skills, stimulating creativity and sensory-motor skills development; the (DLGS)could measure the contribution of digital learning games to the learning process in a local or a global context. Teachers should be also encouraged to use digital games in the learning process as they contribute to the development of many dimensions in the learning process. This encouragement could be done through professional development programs ([6],[37]), where these programs encourage the use of digital games in teaching and learning.

In addition to the above the researchers recommend to conduct future studies to measure the contribution of digital learning games to teaching and learning processes according to various variables, which could lead to new results and conclusions regarding Digital learning games. 


\section{$7 \quad$ References}

[1] Pektas, M., \& Kepceoglu, I. (2019). What Do Prospective Teachers Think about Educational Gamification? Science Education International, 30(1), 65-74.

[2] Baya'a, N., \& Daher, W. (2010). Middle school students' learning of mathematics using mobile phones: Conditions and consequences. Journal of Interactive Learning Research, 21(2), 165-185.

[3] Baya'a, N., \& Daher, W. (2015). Facebook as an educational environment for mathematics learning. In G. Mallia (ed.), STEM Education: Concepts, Methodologies, Tools, and Applications (pp. 406-425). IGI Global. https://doi.org/10.4018/978-1-4666-7363-2.ch022

[4] Baya'a, N., \& Daher, W. (2013). Mathematics Teachers' Readiness to Integrate ICT in the Classroom. International Journal of Emerging Technologies in Learning, 8(1), 46-52.

[5] Bozkurt, G., \& Ruthven, K. (2017). Classroom-based professional expertise: A mathematics teacher's practice with technology. Educational Studies in Mathematics, 94(3), 309328. https://doi.org/10.1007/s10649-016-9732-5

[6] Baya'a, N., Daher, W., \& Anabousy, A. (2019). The Development of In-Service Mathematics Teachers' Integration of ICT in a Community of Practice: Teaching-in-Context Theory. International Journal of Emerging Technologies in Learning, 14(1), 125-139. https://doi.org/10.3991/ijet.v14i01.9134

[7] Thakral, P. (2015). Role of ICT in Professional Development of Teachers. Learning Community-An International Journal of Educational and Social Development, 6(1), 127-133.

[8] Tokan, M. K, Imakulate, M. M. (2019). The effect of motivation and learning behavior on student achievement. South African Journal of Education, 39(1), 313-321.

[9] Seaborne, K., \& Fels, D. I. (2015). Gamification in theory and action: A survey. International Journal of Human-Computer Studies, 74, 14-31.

[10] McGonigal, J. (2011). Reality is broken: Why games make us better and how they can change the world. New York: Penguin.

[11] Kapp, K. M. (2012). The gamification of learning and instruction: game-based methods and strategies for training and education. John Wiley \& Sons.

[12] J. Kahila, T. Valtonen, M. Tedre, K. Mäkitalo, and O. Saarikoski, "Children's Experiences on Learning the 21st-Century Skills With Digital Games," Games Cult., vol. 15, no. 6, pp. 685-706, 2020. https://doi.org/10.1177/1555412019845592

[13] Begosso, L.R., Cunha, D. S., Pinto, J. B., Lemos, L.T., \& Nunes, M. J. (2018). The Use of Gamification for Teaching Algorithms, Communication Papers of the Federated Conference on Computer Science and Information Systems. Poznan, Poland, FL. https://annalscsis.org/Volume_17. https://doi.org/10.15439/2018f165

[14] Hamari, J., Shernoff, D. J., Rowe, E., Coller, B., Asbell-Clarke, J \& ,.Edwards, T. (2016). Challenging games help students learn: An empirical study on engagement, flow and immersion in game-based learning. Computers in human behavior, 54, 170-179. https://doi.org/10.1016/j.chb.2015.07.045

[15] Romero, M., Usart, M., \& Ott, M. (2015). Can serious games contribute to developing and sustaining 21st century skills? Games and Culture, 10(2), 148-177. https://doi.org/ $\underline{10.1177 / 1555412014548919}$

[16] Piller, Y., \& Roberts-Woychesin, J. (2015, May). Raising Parental Awareness about Game-based Learning. In Proceedings of the 7th International Conference on Computer Supported Education-Volume 2 (pp. 385-389). SCITEPRESS-Science and Technology Publications, Lda. https://doi.org/10.5220/0005406203850389

[17] Donmez, I., Tekce, M. \& Kirmit, S. (2020). Using digital games in technology-oriented STEM education: The examination of the students' game designs. Journal of Education in 
Science, Environment and Health (JESEH), 6(2), 77-91. https://doi.org/10.21891/jeseh. $\underline{669097}$

[18] Uzunboylu, H., Galimova, E., Kurbanov, R., Belyalova, A., Deberdeeva, N. \& Timofeeva, M. (2020). The Views of the Teacher Candidates on the Use of Kahoot as A Gaming Tool. International Journal of Emerging Technologies in Learning (iJET), https://doi.org/10.3991/ijet.v15i23.18811

[19] Chen, S., Yang, C., Huang, C.\& Fu, Sh. (2019). Digital games for learning energy conservation: A study of impacts on motivation, attention, and learning outcomes. Innovations in Education and Teaching International, 56(1), 66-76. https://doi.org/10.1080/14703297. $\underline{2017.1348960}$

[20] Tokarieva, A. V., Volkova, N. P., Harkusha, I. V., \& Soloviev, V. N. (2019). Educational digital games: models and implementation. In Proceedings of the 6th Workshop on Cloud Technologies in Education (CTE 2018), Kryvyi Rih, Ukraine, December 21, 2018 (No. 2433, pp. 74-89). CEUR Workshop Proceedings.

[21] Byun, J \& ,.Loh, C. S. (2015). Audial engagement: Effects of game sound on learner engagement in digital game-based learning environments. Computers in Human Behavior, 46, 129-138. https://doi.org/10.1016/j.chb.2014.12.052

[22] Malik, S., Al-Emran, M., Mathew, R., Tawafak, R. \& Alfarsi, G. (2020). Comparison of ELearning, M-Learning and Game-based Learning in Programming Education - A Gendered Analysis. International Journal of Emerging Technologies in Learning (iJET), 15(15), 133-146. https://doi.org/10.3991/ijet.v15i15.14503

[23] Furdu, I., Tomozei, C., \& Köse, U. (2017). Pros and Cons Gamification and Gaming in Classroom, Broad Research in Artificial Intelligence and Neuroscience, 8(2), 56-62.

[24] Liat, A. (2016). Digital games in learning. Lexi-Kay, 6, 15-16.

[25] Riberio, M. C. (2019). Analog and digital games as a pedagogical tool in the teacher training context. Research in Social Sciences and Technology, 4(2),163-173.

[26] Noemí, P.-M., \& Máximo, S. H. (2014). Educational games for learning. Universal Journal of Educational Research, 2(3), 230-238.

[27] Inna, A., Wadim, S.,Anna, R., Alla. M. (2020). Does Playing Video Games Increase Emotional Creativity? International Journal of Environmental Research and Public Health. 17, $1-12$.

[28] Arnab, S., Clarke, S., and Morini, L. (2019). Co-Creativity through Play and Game Design Thinking. The Electronic Journal of e-Learning, 17(3), pp. 184-198, available online at www.ejel.org https://doi.org/10.34190/jel.17.3.002

[29] Karbach, J. \& Schubert, T. (2013). Training- induced cognitive and natural plasticity Frontiers in human Neuroscience, 7, 6-7.

[30] Satria, P., Bobby, M., Reny N (2019). Understanding the Generation Z Behavior on DLearning: A Unified Theory of Acceptance and Use of Technology (UTAUT) Approach. International Journal of Emerging Technologies in Learning (iJET), 14(5), 20-33. https:// doi.org/10.3991/ijet.v14i05.9993

[31] Daher, W. (2019, February). Assessing students' perceptions of democratic practices in the mathematics classroom. In Eleventh Congress of the European Society for Research in Mathematics Education (No. 6). Freudenthal Group; Freudenthal Institute; ERME.

[32] Akay, E., Aypay (2016). School Effectiveness and Comparison of the Effectiveness of Turkish State Secondary Schools According to Socioeconomic Status. The Turkish Online Journal of Educational Technology, 15 (3), 453-467.

[33] Abd Rabo, A; Hashaikeh, Sh. (2020). Assessing School Principals' Perceptions of School Effectiveness in the Palestinian Schools Universal Journal of Educational Research 8(11): 5536-5546. https://doi.org/10.13189/ujer.2020.081157 
[34] Morgenstern, O., Pinto, I., Wagerhof A., Hoffman, T., Lotti, S., (2019). Future-oriented pedagogy, principles, implications and applications. Jerusalem, Israel: Ministry of Education.

[35] Barak, M. (2017). Science teacher education in the twenty-first century: A pedagogical framework for technology-integrated social constructivism. Research in Science Education, 47(2), 283-303. https://doi.org/10.1007/s11165-015-9501-y

[36] Obschonka, M., Hakkarainen, K., Lonka, K., \& Salmela-Aro, K. (2017). Entrepreneurship as a twenty-first century skill: entrepreneurial alertness and intention in the transition to adulthood. Small Business Economics, 48(3), 487-501. https://doi.org/10.1007/s11187016-9798-6

[37] Daher, W. (2014). Students' Adoption of Social Networks as Environments for Learning and Teaching: The Case of the Facebook. International Journal of Emerging Technologies in Learning, 9(4), 16-24. https://doi.org/10.3991/ijet.v9i8.3722

\section{Authors}

Yasmeen Abu Mukh, (Yasmeen) Ph.D. student at program of learning and teaching at An-Najah National University. M.A in Special Education at Tel Aviv University, Bachelor's Degree in Special Education and Arabic Language at Al-Qasemi Academy, Isreal, Lecturer and supervisor at Al-Qasemi College in Special Education Department.

Sherine Hashaikeh, (Sherine) Ph.D. student at program of learning and teaching at An-Najah National University. M.A in Educational Administration at An Najah National University, Bachelor's Degree in French Language and Literature at An Najah National University, School Principal in Nablus.

Aysha Abd-Rabo, (Aysha) $\mathrm{PhD}$ student at program of learning and teaching at An-Najah National University, M.A in Educational Administration at An Najah National University, bachelor's degree in Business Administration at an Najah university - Nablus-Palestine.

Article submitted 2020-12-22. Resubmitted 2021-02-09. Final acceptance 2021-02-14. Final version published as submitted by the authors. 